\title{
Acceptance of COVID-19 Vaccination in India after the First Phase-Out: A Cross-Sectional Community-Based Study
}

\author{
Neetu Shukla ${ }^{1}$ Monika Agarwal ${ }^{1}$ Anish Khanna ${ }^{1}$ Amritesh Chandra Shukla ${ }^{2}$ Anila Varghese ${ }^{1}$ \\ ${ }^{1}$ Department of Community Medicine and Public Health, King \\ George's Medical University, Lucknow, Uttar Pradesh, India \\ 2 Department of Botany, Faculty of Science, University of Lucknow, \\ Lucknow, Uttar Pradesh, India \\ Address for correspondence Neetu Shukla, MD, Department of \\ Community Medicine and Public Health, King George's Medical \\ University, Lucknow 226001, Uttar Pradesh, India \\ (e-mail: neetupms@gmail.com).
}

Ann Natl Acad Med Sci (India) 2022;58:92-99.

\begin{abstract}
Keywords

- COVID-19

- vaccine acceptance

- vaccine hesitancy

- India

Background India rolled out the world's largest vaccination program on January 16 , 2021 , marking the beginning of an effort to vaccinate a population of 1.3 billion against coronavirus disease 2019 (COVID-19) infection. However, the hesitancy toward safe and effective vaccine against severe infection is a major global health threat. Hence, public acceptance of COVID-19 vaccine would be an essential deterrent to the pandemic control.

Materials and Methods A cross-sectional online study was conducted among the Indians from January 1 to January 31, 2021. The online questionnaire addressed several variables, including the sociodemographic parameters, COVID-19 vaccine acceptance, and concerns regarding COVID-19 vaccine.

Results Out of total 450 participants, majority of them (97.1) were aware about the COVID-19 vaccination drive. Only $66.2 \%$ showed their willingness to accept vaccination, $26.0 \%$ were still indecisive, and $7.8 \%$ did not want to accept it.

Conclusion Despite numerous efforts by various scientific organizations, public health experts, and media outlets, to educate the general population about the COVID-19 vaccine, significant portion of the Indian population may experience vaccine hesitancy, which poses dangers to both the individual and their community. Therefore, we must target these potential candidates, who are indecisive, for intervention to increase vaccine acceptance across the country. In this regard, large-scale study is required to understand the knowledge, expectation, and apprehension covering various economic and occupational strata of the society.
\end{abstract}

\section{Introduction}

The coronavirus disease 2019 (COVID-19) infection is caused by severe acute respiratory syndrome (SARS)-associated coronavirus, which was initially detected in Wuhan, China, in the month of December 2019. This virus spread rapidly throughout the world and on January 27, 2020, its first case published online March 7, 2022
DOI https://doi.org/ 10.1055/s-0042-1743136. ISSN $0379-038 X$.

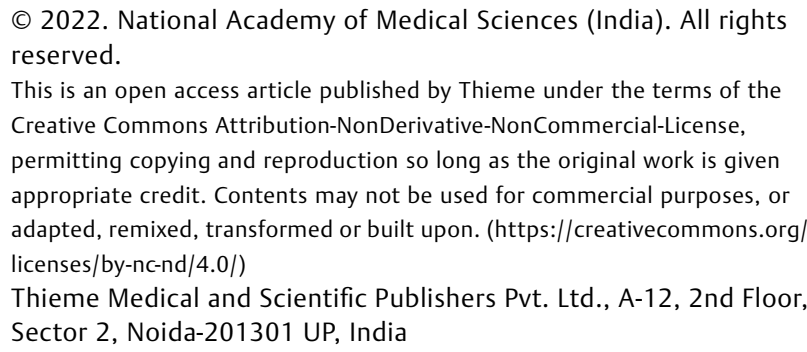

(C) 2022. National Academy of Medical Sciences (India). All rights reserved.

This is an open access article published by Thieme under the terms of the Creative Commons Attribution-NonDerivative-NonCommercial-License, permitting copying and reproduction so long as the original work is given appropriate credit. Contents may not be used for commercial purposes, or adapted, remixed, transformed or built upon. (https://creativecommons.org/ licenses/by-nc-nd/4.0/)

Thieme Medical and Scientific Publishers Pvt. Ltd., A-12, 2nd Floor, Sector 2, Noida-201301 UP, India 
was confirmed in India. Later, on March 11, 2020, the World Health Organization (WHO) declared COVID-19 as a worldwide pandemic. ${ }^{1}$ Further, in the absence of any highly effective therapeutic agent for COVID-19, the development of vaccines that would provide protection from SARS-CoV-2 -severe acute respiratory syndrome coronavirus-2-infection, emerged as global imperative.

The Drug Controller General of India approved two Corona virus vaccines, Covishield (the Indian variant of the AZD1222 vaccine developed by Oxford University and AstraZeneca) and Covaxin (made by Bharat Biotech International Ltd.), after the recommendations of Central Drugs and Standards Committee, for restricted emergency use. Further, on January 16, 2021, massive countrywide COVID-19 vaccination drive was launched successfully. ${ }^{2}$

In the beginning, the priority groups included were health workers and frontline workers. There was considerable enthusiasm and anticipation for the COVID-19 vaccine; however, doubts about its safety and efficacy among the people in several states in India led to the struggle with low turnouts. Moreover, vaccine hesitancy is not a novel phenomenon; there are population subgroups around the world with high vaccine hesitancy, as reported before the COVID-19 pandemic. $^{3-5}$ Vaccine hesitancy is defined as "delay in acceptance or rejection of vaccine, despite the easy availability of vaccination services," by the WHO Strategic Advisory Group of Experts on immunization. ${ }^{6,7}$ As little is known about vaccine hesitancy specifically for COVID-19 in the Indian population, we planned to conduct a comprehensive assessment of COVID-19-related vaccine acceptance in India and to identify population subgroups with higher probability of vaccine hesitancy, and thus improving its acceptance among general people.

\section{Materials and Methods}

\section{Study Design, Setting, and Participants}

A cross-sectional survey-based study was conducted from January 1 to January 31, 2021. A convenience sample approach was adopted in this study, where people aged 18 years and above, living in various States and Union Territories of India, were invited to participate.

\section{Sample Size}

Assuming prevalence of vaccine acceptance as 50\%, Schwartz formula was applied. Using $90 \%$ power with $95 \%$ confidence level, the sample size came out to be 400 .

\section{Procedure}

A bilingual (English/Hindi) semi-structured questionnaire was prepared. Sections 1 and 2 contained detailed information and consent about the survey. Section 3 had sociodemographic details and information related to any chronic infection in family as well as COVID-19 infection in family. Section 4 contained questions related to awareness and perception of the participants related to COVID-19 infection and its vaccination. Section 5 explored about their attitude toward vaccination against COVID-19 as well as non-COVID19 infections. Sections 6 and 7 dealt with reasons for either accepting or rejecting COVID-19 vaccination.

The questions were validated based on comprehensive literature review ${ }^{7,8}$ (to ensure face validity) and expert suggestions (to ensure content validity) as well as repeated consultations followed by modifications. A pilot study ( $N=26$ ) was conducted to improve the wording and clarity of expression of the survey items. Data from the pilot study were not used in any further analysis and the questionnaire was remodified, which required an estimated time of 5 to 10 minutes to complete.

Google forms were shared by the researchers within their social media sites, networks such as academic posts, community organizations, and in personal/family groups. Further, the primary participants were requested to forward the survey among their friends and relatives. Indian, 18 years and above, consenting, and willing to spare time to fill the survey were asked to participate in the survey. After receiving and clicking the survey link, participants got auto-directed to the informed consent page, followed by the set of survey questionnaires.

\section{Data Analysis}

The questionnaires were checked for their completeness and consistency. Collected data were exported from the MS Excel spreadsheet into SPSS-Statistical Package for the Social Sciences-for Windows version 24.0 (2016), coded appropriately, and later cleaned for any possible errors. For analysis, responses to the intention to get COVID-19 vaccination section were combined. For example, both responses "No" and "May be" were combined in one category. Descriptive statistics like frequency and percentage (\%) to describe the demographic characteristics of the study participants were used in the study. The main outcome variable of the survey was the public acceptance of COVID-19 vaccines. To determine this, categorical data were presented as percentage (\%), and Pearson's chi-squared test was used to evaluate differences between groups for categorized variables. In case the expected cell count was found to be less than 5 in $>20 \%$ cells, the Fisher's exact test was used. All tests were performed at a $5 \%$ level significance, and thus the value less than 0.05 ( $p$-value $<0.05$ ) was taken as significant association.

\section{Results}

\section{Sociodemographic Factors of the Participants}

Overall, 450 individuals completed the self-administered electronic questionnaire from various States and Union Territories of India (-Fig. 1), out of which more than half of the participants (54.4\%) belonged to the age group 18 to 30 years while individuals of age $>60$ years constituted only $2.7 \%$ of the study population. Majority of the participants were males (59.6\%), Hindu (88.7\%), residing in urban localities $(79.8 \%)$, and graduate and above (75.3\%). Almost half (49.7\%) of them were health care workers and $39.3 \%$ were working in public sector (-Table $\mathbf{1}$ ). 
94 Acceptance of COVID-19 Vaccination in India after the First Phase-Out Shukla et al.

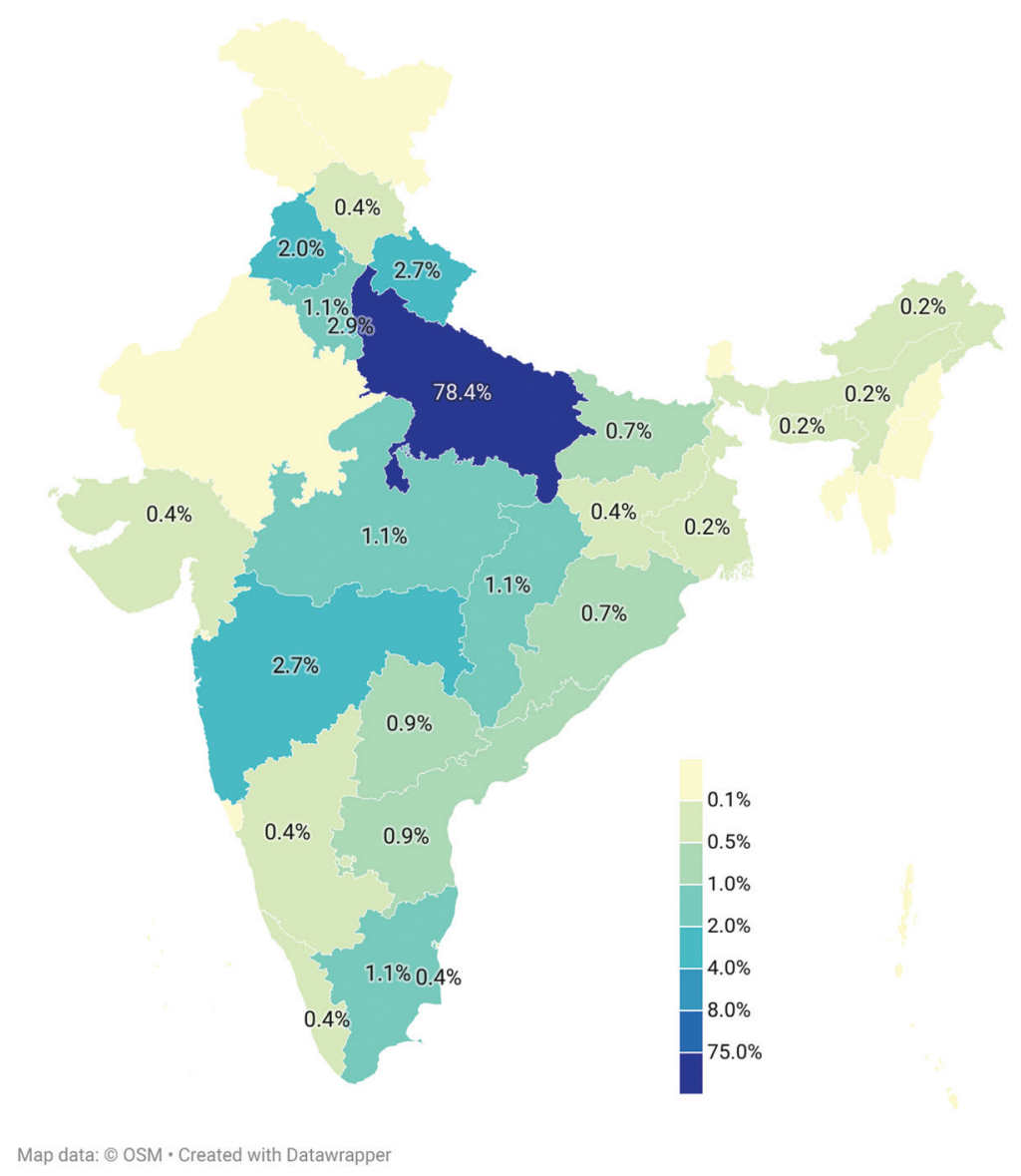

Fig. 1 Participants (\%) from various states/union territories of India.

Table 1 Sociodemographic characteristics of the participants $(n=450)$

\begin{tabular}{|c|c|c|}
\hline \multicolumn{2}{|l|}{ Factors } & Total sample: $\boldsymbol{n}(\%)$ \\
\hline \multirow[t]{3}{*}{ Age (in completed years) } & $\leq 30$ years & $245(54.4)$ \\
\hline & $31-60$ years & $193(42.9)$ \\
\hline & $>60$ years & $12(2.7)$ \\
\hline \multirow[t]{2}{*}{ Gender } & Male & $267(59.3)$ \\
\hline & Female & $183(40.7)$ \\
\hline \multirow[t]{3}{*}{ Religion } & Hindu & $399(88.7)$ \\
\hline & Muslim & $36(8.0)$ \\
\hline & Others & $15(3.3)$ \\
\hline \multirow[t]{2}{*}{ Locality } & Rural & $91(20.2)$ \\
\hline & Urban & $359(79.8)$ \\
\hline \multirow[t]{3}{*}{ Occupation } & Health care workers & $224(49.7)$ \\
\hline & Unemployed/housewives & $44(9.0)$ \\
\hline & Other professionals & $182(40.4)$ \\
\hline \multirow[t]{3}{*}{ Employee sector } & Public & $177(39.3)$ \\
\hline & Private & $145(32.2)$ \\
\hline & Others & $128(28.4)$ \\
\hline \multirow[t]{2}{*}{ Education } & Graduate and above & $339(75.3)$ \\
\hline & Below graduate & $111(24.7)$ \\
\hline
\end{tabular}

Note: $n(\%)$ indicates frequency and percentage of individuals who selected an option on the variables. 
Table 2 Association of vaccine acceptance response and perception about COVID-19 infection among participants $(n=450)$

\begin{tabular}{|c|c|c|c|c|c|}
\hline \multirow{2}{*}{\multicolumn{2}{|c|}{ Associated variables }} & \multicolumn{2}{|c|}{$\begin{array}{l}\text { Acceptance of vaccina- } \\
\text { tion against COVID-19 } \\
\text { infection }\end{array}$} & \multirow[t]{2}{*}{ Total: $n(\%)$} & \multirow[t]{2}{*}{$p$-Value ${ }^{a}$} \\
\hline & & Yes: $n(\%)$ & No: $n(\%)$ & & \\
\hline \multirow{3}{*}{$\begin{array}{l}\text { Do you think you are at risk of contracting } \\
\text { COVID-19 infection in the next } 1 \text { year? }\end{array}$} & Very likely & $169(69.8)$ & $73(30.2)$ & $242(53.8)$ & \multirow[t]{3}{*}{0.096} \\
\hline & Not at all & $67(66.3)$ & $34(33.7)$ & $101(22.4)$ & \\
\hline & Cannot say & $62(57.9)$ & $45(42.1)$ & $107(23.8)$ & \\
\hline \multirow[t]{3}{*}{$\begin{array}{l}\text { How severe do you think } \\
\text { COVID-19 infection is? }\end{array}$} & $\begin{array}{l}\text { Does not cause } \\
\text { severe infection }\end{array}$ & $155(61.8)$ & $96(38.2)$ & $251(55.8)$ & \multirow[t]{3}{*}{0.082} \\
\hline & Cannot say & $44(63.8)$ & $25(36.2)$ & $69(15.3)$ & \\
\hline & It causes severe infection & $99(76.2)$ & $31(23.80)$ & $130(28.9)$ & \\
\hline
\end{tabular}

Abbreviation: COVID-19, coronavirus disease 2019.

Note: $n(\%)$ indicates frequency and percentage of individuals who selected an option on the variables.

${ }^{a} p<0.05, p$-value indicates level of $\alpha$ for statistical significance.

\section{Perception about COVID-19 Infection among the Participants}

As per - Table 2, the study shows that around half (53.8\%) of the participants believed that they are at risk of contracting COVID-19 infection in next 1 year and think that it does not cause severe infection (55.8\%). However, this has no significant association with their vaccine acceptance.

\section{Information about COVID-19 Vaccination among the Participants}

Most common sources of information related to COVID-19 vaccine were television/radio (45.3\%) and social media (42.2\%), followed by newspaper (29.1\%) and medical literature (22.7\%; -Fig. 2). But majority (62.7\%) of them felt that they have received only "some information" and trust their source (67.6\%) for vaccine. Participants who were graduate and above, and living in urban areas, were found to be more informed about vaccination as compared to others $(p<0.05)$. Only half of the participants believed that vaccine can protect them from COVID-19 infection (51.1\%) and is safe (52.4\%), whereas $40 \%$ were still found indecisive about it.

\section{COVID-19 Vaccine-Related Preferences among Study Population}

Out of total 450 participants, $66.8 \%$ felt that COVID-19 vaccine can save them and their family from the COVID-19 infection. Further, $44.7 \%$ of them believed that benefit of taking vaccine is more than the risk (-Fig. 3). However, $26 \%$ of the participants were still indecisive and $7.8 \%$ showed their unwillingness in accepting vaccination. Most common

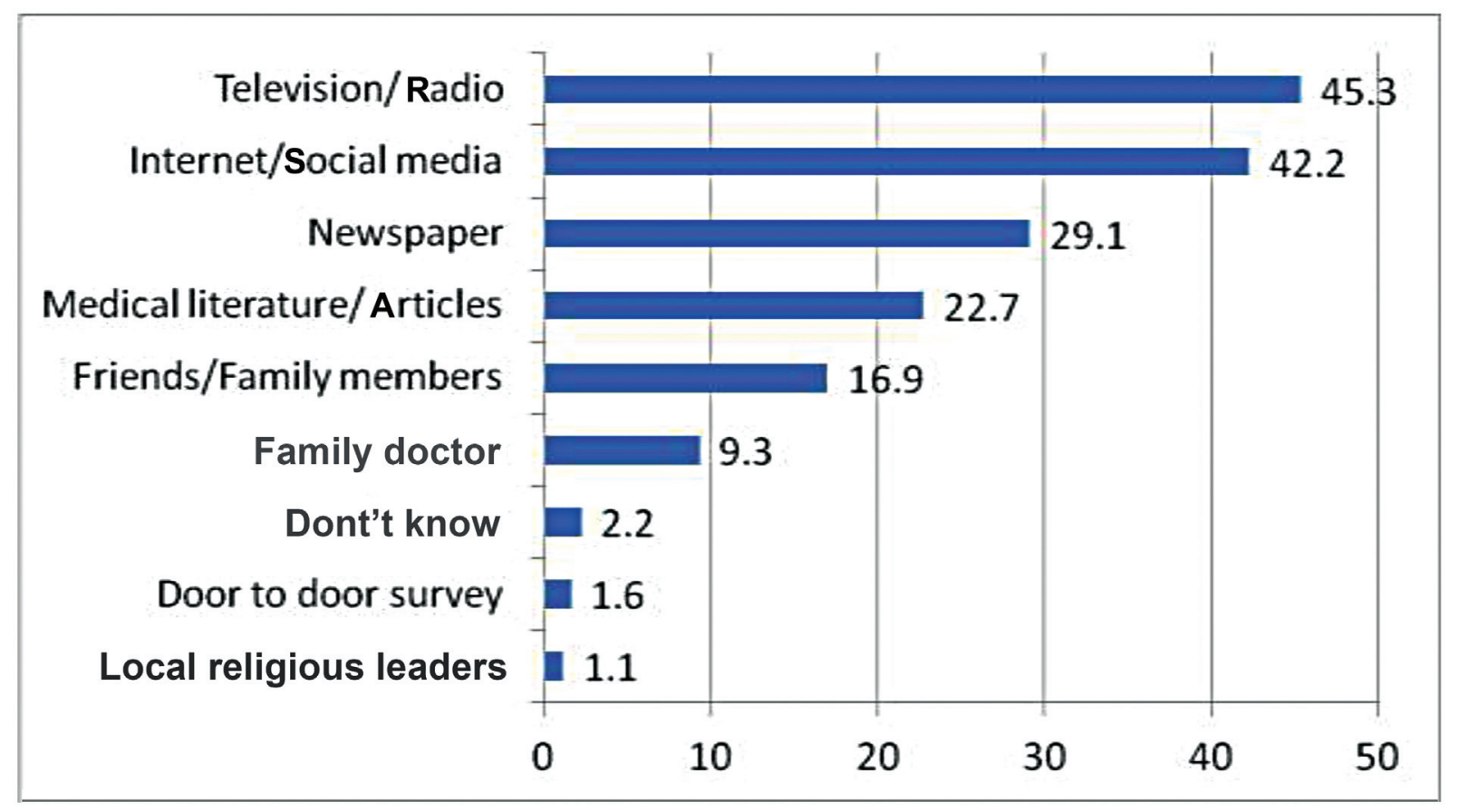

Fig. 2 Source of information regarding coronavirus disease 19 vaccine (percentages may not add to 100 due to multiple responses). 


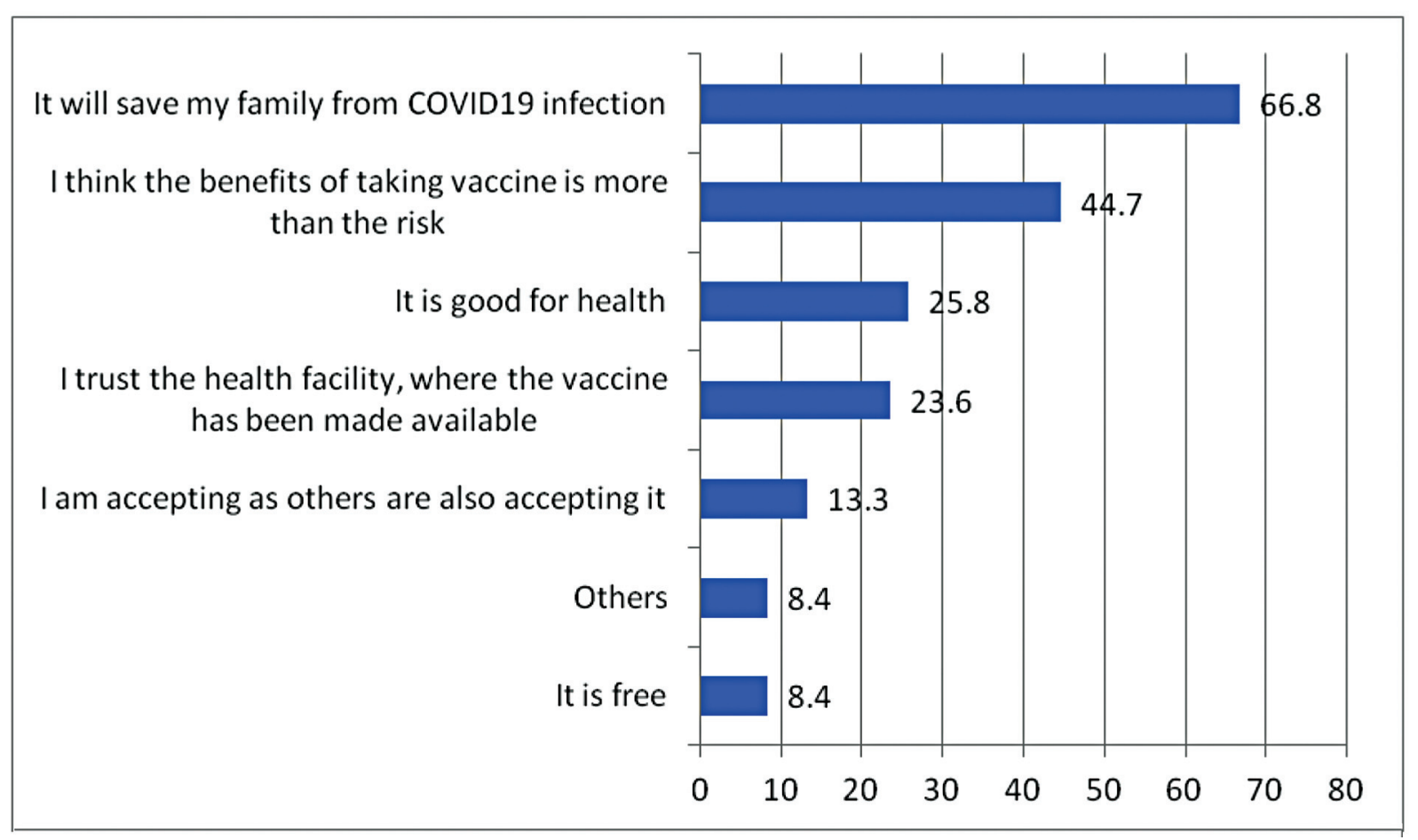

Fig. 3 Reasons for "accepting" coronavirus disease 19 (COVID-19) vaccine (percentages may not add to 100 due to multiple responses).

reason for not accepting was lack of enough scientific evidence $(40.8 \%)$ and "waiting for others to get vaccinated first" (34.8\%; - Fig. 4).

Factors Associated with COVID-19 Vaccine Acceptance The observations, as recorded in - Table 3, show that factors significantly associated with COVID-19 vaccine acceptance were gender (male), age group (31-60 years), religion
(Hindu), and chronic disease status of family $(p<0.05)$. Similarly, in - Table 4, it was seen that respondents who were aware about vaccine drive by the government, who have received most of the information about it, who trusted their source of information, and thus believed that COVID19 vaccine was safe for them and their family members were found more likely to accept COVID-19 $(p<0.05)$ than others.

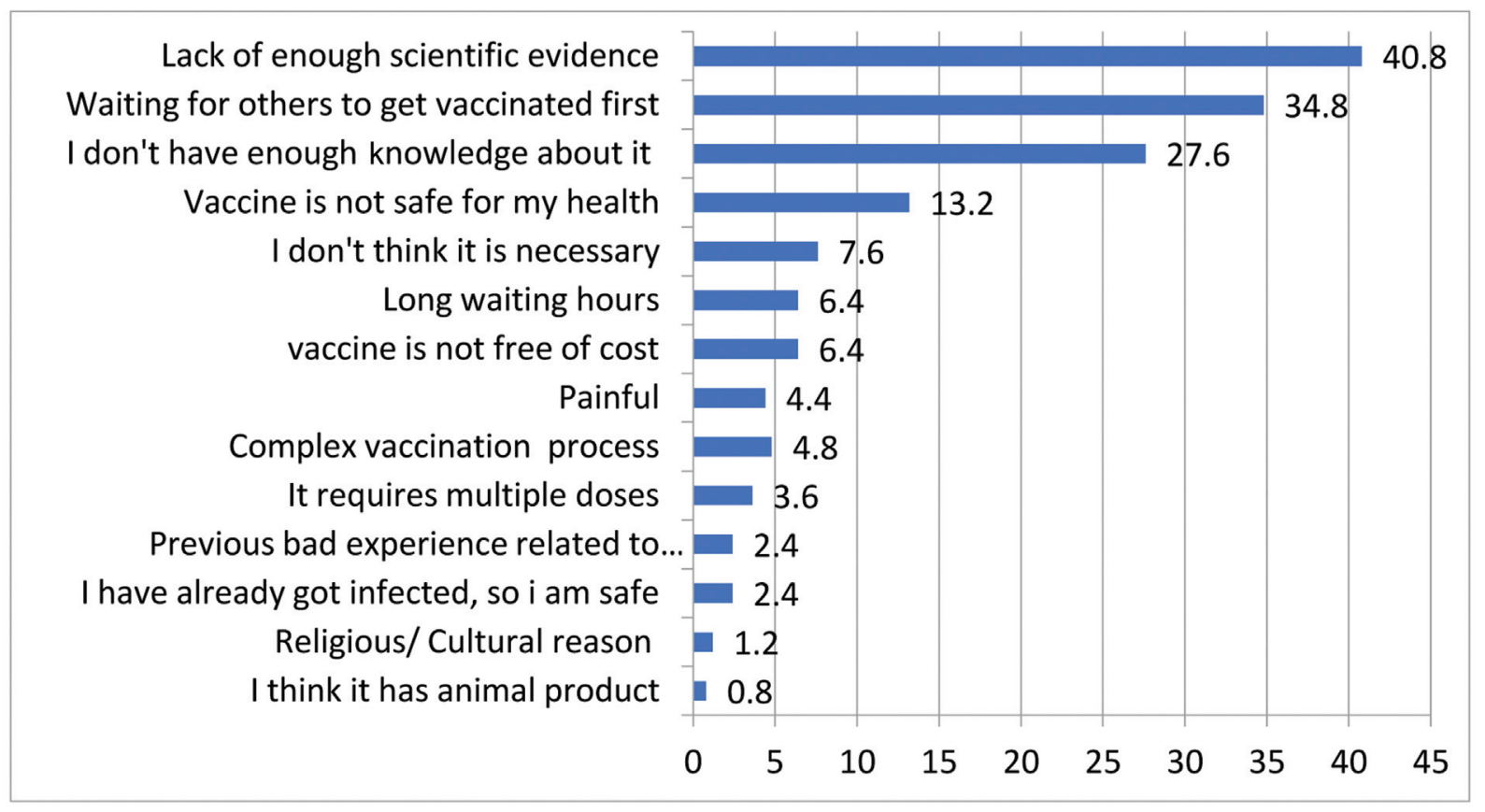

Fig. 4 Reasons for "not accepting" coronavirus disease 19 vaccine (percentages may not add to 100 due to multiple responses). 
Table 3 Association of vaccine acceptance response and sociodemographic factors $(n=450)$

\begin{tabular}{|c|c|c|c|c|c|}
\hline \multirow[t]{2}{*}{ Factors } & & \multicolumn{2}{|c|}{$\begin{array}{l}\text { Acceptance of vaccination } \\
\text { against COVID-19 infec- } \\
\text { tion }\end{array}$} & \multirow[t]{2}{*}{ Total: $\boldsymbol{n}(\%)$} & \multirow[t]{2}{*}{$p$-Value ${ }^{a}$} \\
\hline & & Yes: $\boldsymbol{n}(\%)$ & No: $n(\%)$ & & \\
\hline \multirow[t]{3}{*}{ Age (in completed years) } & $\leq 30$ years & $142(58.0)$ & $103(42.0)$ & $245(54.4)$ & \multirow[t]{3}{*}{$<0.001$} \\
\hline & $31-60$ years & $146(75.6)$ & $47(24.4)$ & $193(42.9)$ & \\
\hline & $>60$ years & $10(83.3)$ & $2(16.7)$ & $12(2.7)$ & \\
\hline \multirow[t]{2}{*}{ Gender } & Male & $190(71.2)$ & $77(28.8)$ & $267(59.3)$ & \multirow[t]{2}{*}{0.007} \\
\hline & Female & $108(59.0)$ & $75(41.0)$ & $183(40.7)$ & \\
\hline \multirow[t]{3}{*}{ Religion } & Hindu & $274(68.7)$ & $125(31.3)$ & $399(88.7)$ & \multirow[t]{3}{*}{0.004} \\
\hline & Muslim & $19(52.8)$ & $17(47.2)$ & $36(8.0)$ & \\
\hline & Others & $5(33.3)$ & $10(66.7)$ & $15(3.3)$ & \\
\hline \multirow[t]{2}{*}{ Locality } & Rural & $65(71.4)$ & $26(28.6)$ & $91(20.2)$ & \multirow[t]{2}{*}{0.240} \\
\hline & Urban & $233(64.9)$ & $126(35.1)$ & $359(79.8)$ & \\
\hline \multirow[t]{2}{*}{ Education } & Graduate and above & $231(68.1)$ & 108 (31.9) & $339(75.3)$ & \multirow[t]{2}{*}{0.132} \\
\hline & Intermediate and below & $67(60.4)$ & $44(39.6)$ & $111(24.7)$ & \\
\hline \multirow[t]{3}{*}{ Occupation } & Health workers & $151(67.4)$ & $73(32.6)$ & $224(49.7)$ & \multirow[t]{3}{*}{0.380} \\
\hline & Unemployed/housewife & $25(56.8)$ & $19(43.2)$ & $44(9.0)$ & \\
\hline & Other professionals & $122(67.0)$ & $60(33.0)$ & $182(40.4)$ & \\
\hline \multirow{2}{*}{$\begin{array}{l}\text { Are you or any family } \\
\text { member suffering from any } \\
\text { of the longstanding chronic } \\
\text { diseases ( }>2 \text { months)? }\end{array}$} & No chronic disease & $240(64.0)$ & $135(36.0)$ & $375(83.3)$ & \multirow[t]{2}{*}{0.025} \\
\hline & Chronic disease present & $58(77.3)$ & $17(22.7)$ & $75(16.7)$ & \\
\hline \multirow{2}{*}{$\begin{array}{l}\text { Have you or any of your family } \\
\text { members been infected with } \\
\text { COVID-19 infection? }\end{array}$} & No & $252(66.0)$ & $130(34.0)$ & $382(84.9)$ & \multirow[t]{2}{*}{0.787} \\
\hline & Yes & $46(67.6)$ & $22(32.4)$ & $68(15.1)$ & \\
\hline
\end{tabular}

Abbreviation: COVID-19, coronavirus disease 2019.

Note: $n(\%)$ indicates frequency and percentage of individuals who selected an option on the variables.

${ }^{a} p<0.05$; $p$-value indicates level of $\alpha$ for statistical significance.

Table 4 Association of vaccine acceptance response and attitude and awareness toward COVID-19 vaccine among the participants $(n=450)$

\begin{tabular}{|c|c|c|c|c|c|}
\hline \multicolumn{2}{|l|}{ Associated variables } & \multicolumn{2}{|c|}{$\begin{array}{l}\text { Acceptance of vaccination } \\
\text { against COVID-19 infection }\end{array}$} & \multirow[t]{2}{*}{ Total: $n$ (\%) } & \multirow[t]{2}{*}{$p$-Value } \\
\hline & & Yes: $n(\%)$ & No: $n(\%)$ & & \\
\hline \multirow{2}{*}{$\begin{array}{l}\text { In past, have you ever refused } \\
\text { any vaccine for yourself or your } \\
\text { children? }\end{array}$} & Yes & $2(33.3)$ & $4(66.7)$ & $6(1.3)$ & \multirow[t]{2}{*}{0.081} \\
\hline & No & $296(66.7)$ & $148(33.3)$ & $444(98.7)$ & \\
\hline \multirow{3}{*}{$\begin{array}{l}\text { Do you believe that vaccine } \\
\text { can protect you from COVID- } \\
19 \text { infection? }\end{array}$} & Very likely & $160(69.3)$ & $71(30.7)$ & $231(51.3)$ & \multirow[t]{3}{*}{0.108} \\
\hline & Not at all & $4(40.0)$ & $6(60.0)$ & $10(2.2)$ & \\
\hline & May be & $134(64.1)$ & 75 (35.9) & $209(46.4)$ & \\
\hline \multirow{3}{*}{$\begin{array}{l}\text { Do you believe that COVID-19 } \\
\text { vaccine is safe for you and your } \\
\text { family members? }\end{array}$} & Very likely & $218(92.4)$ & $18(7.6)$ & $236(52.4)$ & \multirow[t]{3}{*}{$<0.001$} \\
\hline & Do not Know & $78(39.6)$ & $119(60.4)$ & $197(43.8)$ & \\
\hline & Not at all & $2(11.8)$ & $15(88.2)$ & $17(3.8)$ & \\
\hline \multirow{3}{*}{$\begin{array}{l}\text { Are you aware that Govern- } \\
\text { ment of India is starting vac- } \\
\text { cination drive? }\end{array}$} & Yes & $296(67.7)$ & $141(32.3)$ & $437(97.1)$ & \multirow[t]{2}{*}{$<0.001$} \\
\hline & No & $2(15.4)$ & $11(84.6)$ & $13(2.9)$ & \\
\hline & No information & $24(53.3)$ & $21(46.7)$ & $45(10.0)$ & 0.002 \\
\hline
\end{tabular}


Table 4 (Continued)

\begin{tabular}{|l|l|l|l|l|}
\hline \multicolumn{2}{|l|}{ Associated variables } & \multicolumn{2}{l|}{$\begin{array}{l}\text { Acceptance of vaccination } \\
\text { against COVID-19 infection }\end{array}$} & \multirow{2}{*}{ Total: $\boldsymbol{n}(\%)$} \\
\cline { 3 - 5 } & Yes: $\boldsymbol{n}(\%)$ & No: $\boldsymbol{n}(\%)$ & \\
\hline $\begin{array}{l}\text { Do you feel you have got } \\
\text { enough information about } \\
\text { Coronavirus vaccine? }\end{array}$ & Some information & $178(63.1)$ & $104(36.9)$ & $282(62.7)$ \\
\cline { 2 - 5 } & Most information & $96(78.0)$ & $27(22.0)$ & $123(27.3)$ \\
\hline $\begin{array}{l}\text { Do you trust the source from } \\
\text { where you received informa- } \\
\text { tion regarding vaccination? }\end{array}$ & Very likely & $235(77.3)$ & $69(22.7)$ & $304(67.6)$ \\
\cline { 2 - 5 } & Not at all & $7(25.9)$ & $20(74.1)$ & $27(6.0)$ \\
\cline { 2 - 5 } & May be & $56(47.1)$ & $63(52.9)$ & $119(26.4)$ \\
\hline
\end{tabular}

Abbreviation: COVID-19, coronavirus disease-2019.

\section{Discussion}

There are limited studies to explore the intention for uptake of COVID-19 vaccine in the current pandemic crisis. In a cross-sectional study conducted in October 2020 of 351 Indian adults, it was found that $86.3 \%$ were planning to get COVID-19 vaccination whereas $13.7 \%$ admitted hesitancy. ${ }^{9}$ Further, during July-October 2020, another study of 513 residents of Delhi recorded that $79.5 \%$ participants showed their willingness to take the vaccine while $8.8 \%$ were not of the opinion to take the vaccine and remaining $11.7 \%$ had not yet decided about the vaccine. ${ }^{10}$ Similarly, in the current study, it was observed that most of the participants (97.1) were quite aware about the COVID-19 vaccination. However, only $66.2 \%$ showed their willingness to accept vaccination and $26.0 \%$ were still indecisive whereas $7.8 \%$ did not want to accept it.

Moreover, these differences in acceptance of vaccine could also be in part due to the different timing of studies conducted in COVID-19 pandemic. Besides this, in the current study it was also recorded that people's occupation, locality, and education played significant roles.

Various studies reported the perceived risk of becoming infected as predictor toward intention behind vaccination. ${ }^{11-14}$ Further, high trust in the source of information and level of information about the vaccine were associated with the acceptance of COVID-19 vaccination. ${ }^{15-17}$ Similarly, in the current study, participants having high trust in the information system and having awareness and enough information were found more willing to accept COVID-19 vaccination. Men perceived more risk of infection than women as they thought they were more exposed and informed. Thus, significant gender gap was identified. Locality (urban/rural) and religion also seemed to affect their behavior, which highlighted them as target groups. Health workers were found willing to accept vaccination as they were more informed, exposed, and perceived COVID-19 as very severe infection while working during pandemic as compared with other professionals.

The present study revealed that only half of the participants believed that vaccine could protect them from COVID-19 infection (51.1\%) and was safe (52.4\%) whereas more than $40 \%$ were indecisive. Thus, we must acknowledge this uncer- tainty, combating misinformation, myths, misperceptions, and conspiracy theories that can influence vaccine acceptance behavior. Further, people living in rural areas believed COVID-19 infection was a disease of urban areas, and thus showed unwillingness to vaccination. They had more belief in their local cultural practices and had several myths concerning social and religious values. Interestingly, many people preferred yoga practices, regular disciplined lifestyle, immunity boosters, and Ayurvedic medicines, above the vaccine.

The findings emphasized that there is need for clear and consistent communication by public health experts to build public confidence in vaccination campaign. This includes targeting women, rural people, and professionals other than health workers, and explaining them about the severity and risk of infection and its prevention through vaccination. All information about how vaccines work as well as how they are developed, from recruitment to regulatory approval based on safety and efficacy, should be clearly conveyed. Credible and culturally informed health communication is vital in influencing positive health behaviors ${ }^{15,18}$ and has been observed with respect to encouraging people to cooperate with COVID-19 control measures. Thus, involvement of the public and leaders of civic, religious, and fraternal organizations, who are respected within various sectors of society and local communities, as well as its supplementation with accurate information and technological support will promote mass vaccination program.

\section{Limitation of the Study}

As the current study was conducted majorly in Uttar Pradesh, mainly (around 75\%) among educated (graduate and above) and young adults ( $\leq 30$ years) using an online self-administered questionnaire, therefore it did not have equal representatives from various economic and occupational strata of society, which could result in bias. Thus, large-scale studies from whole of India are needed to understand the knowledge, expectation, and apprehension related to COVID-19 vaccine.

\section{Conclusion}

India needs to immediately rethink its strategy regarding mass vaccination rollout. However, effective campaigns have 
already been initiated to explain about a vaccine's level of effectiveness, the time needed for protection (with multiple doses, if required), and the importance of population-wide coverage to achieve community immunity. But, such communication strategies and techniques to be used during the ongoing pandemic should be transparent, accurate, socially acceptable, and must focus the target groups. It must have partnerships with community members and healthcare professionals. Regarding this, extensive studies from the entire parts of India are needed, to understand the knowledge, expectation, and apprehension, covering various economic and occupational strata of society.

\section{Conflict of Interest}

None declared.

\section{Acknowledgment}

The authors are thankful to the authorities of the Department of Community Medicine and Public Health, King Georges Medical University, Lucknow, and the Department of Botany, University of Lucknow, Lucknow, India, for providing the facilities and support during compilation of the work. The authors are also thankful to the participants involved in this study.

\section{References}

1 Coronavirus disease 2019 (COVID-19) Situation Report-94. Accessed April 23, 2020 at: https://www.who.int/docs/default-source/coronaviruse/situation-reports/20200423-sitrep-94-covid-19.pdf

2 IndiaFightsCorona COVID-19 in India, Vaccination, Dashboard, Corona Virus Tracker. Available at: https://www.mygov.in/covid-19

3 National Academies of Sciences, Engineering, and Medicine. (2020). Framework for equitable allocation of COVID-19 vaccine. Accessed January 19, 2022 at: //www.nap.edu/catalog/25917/ framework-for-equitable-allocation-of-covid-19-vaccine

4 McAteer J, Yildirim I, Chahroudi A. The VACCINES Act: deciphering vaccine hesitancy in the time of COVID-19. Clin Infect Dis 2020;71 (15):703-705

5 World Health Organizations. (2019). Ten threats to global health in 2019. Accessed January 19, 2022 at: https://www.who. int/news-room/spotlight/ten-threats-to-global-health-in-2019
6 MacDonald NESAGE Working Group on Vaccine Hesitancy. Vaccine hesitancy: definition, scope and determinants. Vaccine 2015; 33(34):4161-4164

7 World Health Organization. Department of Immunization, Vaccines and Biologicals (IVB). SAGE October 2014. GenevaWorld Health Organization2014; Accessed January 19, 2022 at: http:// www.who.int/immunization/sage/meetings/2014/october/Yellow-bookSAGE2014_final.pdf?ua=1

8 Sharun K, Rahman F, Haritha V, Jose B, Tiwari R, Dhama K. COVID19 vaccine acceptance: beliefs and barriers associated with vaccination among the general population in India. J Experiment Biol Agricult Sci. 2020;8:S210-S218

9 Islam F, Agarwalla R, Panda M, et al. Assessment of the knowledge, preferences and concern regarding the prospective COVID- 19 vaccine among adults residing in New Delhi, India-a cross sectional study. [Internet]. Doi: 10.1101/2021.01.23.21250164 Accessed January 19, 2022

10 Fu C, Wei Z, Pei S, Li S, Sun X, Liu P. Acceptance and preference for COVID-19 vaccination in health-care workers (HCWs) [Internet]. Epidemiology. 2020. Accessed January 19, 2022 at: http:// medrxiv.org/lookup/doi/10.1101/2020.04.09.20060103

11 Nguyen T, Henningsen KH, Brehaut JC, Hoe E, Wilson K. Acceptance of a pandemic influenza vaccine: a systematic review of surveys of the general public. Infect Drug Resist 2011;4:197-207

12 Gidengil CA, Parker AM, Zikmund-Fisher BJ. Trends in risk perceptions and vaccination intentions: a longitudinal study of the first year of the H1N1 pandemic. Am J Public Health 2012;102 (04):672-679

13 Setbon M, Raude J. Factors in vaccination intention against the pandemic influenza A/H1N1. Eur J Public Health 2010;20(05): 490-494

14 Quinn SC, Jamison AM, An J, Hancock GR, Freimuth VS. Measuring vaccine hesitancy, confidence, trust and flu vaccine uptake: results of a national survey of White and African American adults. Vaccine 2019;37(09):1168-1173

15 Musa D, Schulz R, Harris R, Silverman M, Thomas SB. Trust in the health care system and the use of preventive health services by older black and white adults. Am J Public Health 2009;99(07): 1293-1299

16 Harris KM, Maurer J, Kellermann AL. Influenza vaccine-safe, effective, and mistrusted. N Engl J Med 2010;363(23):2183-2185

17 Shore DA. Communicating in times of uncertainty: the need for trust. J Health Commun 2003;8(Suppl 1):13-14

18 French J, Deshpande S, Evans W, Obregon R. Key guidelines in developing a pre-emptive COVID-19 vaccination uptake promotion strategy. Int J Environ Res Public Health 2020;17(16):E5893 